Now, as Librarian, I again, and not without great trepidation, follow Walk. It is in this context that I would like to register my profound appreciation of the help he has given me in reassembling the Library in its new and permanent home. Without him the Library might still be an elegant but bookless salon.

I have tried as best I can to pay tribute to Alexander Walk, the scholar. Perhaps I need not have bothered. Perhaps I should have just left it to Chaucer, who paid a far more eloquent tribute to him six centuries ago:

'But al that he mighte of his freendes hente, On bokes and on lerninge he it spente.

Of studie took he most cure and most hede, Noght a word spak he more than was nede, and that was seyd in forme and reverence. and short and quick, and ful of hy sentence. Souninge in moral vertu was his speche, And gladly wolde he lerne, and gladly teche.'

Henry R. Rollin

\title{
Dr Walk's Dinner
}

As a tribute to Dr Walk and to mark his fifty years of service to the RMPA and the College, a dinner in his honour was held at the Royal Society of Medicine on Friday, 12 May. The President presided, and past and present Editors and Assistant Editors and Fellows and Members of the College and its staff who have worked closely with Dr Walk over the years were present.

\section{M.R.C. PSYGH. EXAMINATIONS-AUTUMN 1978}

The next M.R.C.Psych. Examinations will take place on the following dates:

Preliminary Test-Wednesday 27 September 1978 Membership Examination (written papers)Wednesday 8 November 1978

Membership Examination (clinicals and orals)Monday 13 to Wednesday 15 November 1978

The closing date for receipt of entries is WEDNESDAY 30 AUGUST 1978.

The written part will be held in London, Birming ham, Glasgow and Dublin; clinical and oral examinations in London, Birmingham and Glasgow.

Late entries WILL NOT BE ACCEPTED. Where candidates have undertaken part-time or overseas experience in psychiatry, or are required to submit the name and address of their Clinical Tutor or Consultant Chief, the entry forms should be submitted at least three weeks in advance so that the application may be finalized before the closing date is reached.
All candidates are required to pass the Preliminary Test before sitting for the Membership Examination.

Regulations and application forms are obtainable from the Examinations Secretary, 17 Belgrave Square, London SW IX 8PG, together with copies of past MCQ and essay question papers at 50p per set for $1971-1975$, 2op per set for 1976 and 25p per set for 1977, inclusive of UK postage. Airmail postage is extra according to zone.

The 4th Edition of the Reading List in Psychiatry is available direct from Messrs Headley Brothers Ltd, Ashford, Kent TN24 8HH, at a cost of 40 including UK postage. Air mail postage extra. Cheques/postal orders should be made payable to 'Headley Brothers Ltd'.

All Members and Fellows are asked to bring this announcement to the notice of any prospective candidates working under their guidance.

\section{ThOMAS BewLeY}

